\title{
Microbial quality of raw cow's milk collected from farmers and dairy cooperatives in Bahir Dar Zuria and Mecha district, Ethiopia
}

\author{
Asaminew Tassew ${ }^{1}$ and Eyassu Seifu ${ }^{2}$ \\ ${ }^{1}$ Lecturer, Bahir Dar University, PO Box 276, Bahir Dar, Ethiopia \\ ${ }^{2}$ Associate Professor, Haramaya University, PO Box 287, Haramaya, Ethiopia \\ atassew2005@yahoo.com, asaminew2@gmail.com
}

\begin{abstract}
This study was carried out to evaluate microbial quality of raw cow's milk taken at different sampling points from farmers and dairy cooperatives in Bahir Dar Zuria and Mecha district. The overall mean total bacterial count, coliform count and percent lactic acid of milk produced in the study area were $7.58 \pm 0.09 \log _{10} \mathrm{cfu} / \mathrm{ml}, 4.49 \pm 0.11 \log _{10} \mathrm{cfu} / \mathrm{ml}$ and $0.23 \% \pm 0.01$, respectively. The hygienic quality of raw cow's milk of the dairy cooperatives was poor with an overall mean total bacteria count, coliform count and percent lactic acid of $8.12 \mathrm{log} \mathrm{cfu} / \mathrm{ml}, 4.94 \mathrm{log} \mathrm{cfu} / \mathrm{ml}$ and 28 percent, respectively. The overall mean of the predicted probabilities of clot-on-boiling and alcohol tests were $0.23 \pm 0.12$ and $0.51 \pm 0.11$, respectively. While, most of the milk samples collected from the dairy cooperatives were likely to clot both by clot-on-boiling and alcohol tests as compared to the samples collected from individual farmers. All the indirect tests and the actual bacterial counts indicated that the microbiological quality of milk produced by farmers and collected by the dairy cooperatives in the study area was poor and this call for scrupulous hygienic measures during production and handling of milk.
\end{abstract}

Keywords: Bacterial counts; coliform count; hygienic measures; Mecha

\section{INTRODUCTION}

The safety of dairy products with respect to food-born diseases is of great concern around the world. This is especially true in developing countries where production of milk and various milk products takes place under unsanitary conditions and poor production practices (Mogessie 1990).

The microbial load of milk is a major factor in determining its quality. It indicates the hygienic level exercised during milking, that is, cleanliness of the milking utensils, condition of storage, manner of transport as well as the cleanliness of the udder of the individual animal (Spreer 1998; Gandiya 2001). Milk from a healthy udder contains few bacteria but it picks up many bacteria from the time it leaves the teat of the cow until it is used for further processing. These microorganisms are indicators of both the manner of handling milk from milking till consumption and the quality of the milk. Milk produced under hygienic conditions from healthy animals should not contain more than $5 \times 105$ bacterial/ml (O'Connor 1994). The purpose of this study was to determine the microbial quality of raw cow's milk at different sampling points received from individual farmers and dairy cooperatives in Bahir Dar Zuria and Mecha district.

\section{MATERIAL AND METHODS}

The study area: This study was conducted in Bahir Dar Zuria and Mecha districts of West Gojjam zone, Ethiopia. Bahir Dar Zuria district is situated at an altitude ranging from 1700-2300 meters above sea level and has area coverage of 151,119 ha. Mecha district is situated at an altitude ranging from 18002500 meters above sea level and has area coverage of 159,898 ha. Annual rainfall for both districts ranged between 820 to $1250 \mathrm{~mm}$ whereas daily temperature ranged between 10 to $32^{\circ} \mathrm{C}$ and 17 and $30^{\circ} \mathrm{C}$ for Bahir Dar Zuria and Mecha districts, respectively.

Milk sampling: Milk samples were collected from households producing milk from local and crossbred cows and also from dairy cooperatives based on the result of the preliminary survey. Accordingly, 7,6 and 2 were the sample units for local cows, crossbred cows and dairy cooperatives, respectively in Bahir Dar Zuria district while 8 and 7 were the sample units for local cows and crossbred cows, respectively in Mecha district. There was no any functional dairy cooperative in Mecha district during the study period and hence this was not considered. Samples of raw morning milk was taken from each household once every month over a period of three months (September, October and November, 2007) for 
microbiological quality analysis following the standard methods as described by Marth (1978). Pooled milk was sampled within 1-2 hours after milking from the farmer's milking containers and the bulk milk of dairy cooperatives. The samples were collected aseptically in sterilized universal bottles, kept in an icebox and transported to the laboratory. Analysis was done one hour after sampling in duplicates. All the analyses were performed within 8 hours of sampling.

Microbial analysis: The microbial tests considered were Standard Plate Count (SPC), Coliform Count (CC), titratable acidity, alcohol test and clot-on-boiling test. For determination of standard plate count and coliform count, peptone water was sterilized by autoclaving at $121^{\circ} \mathrm{C}$ for 15 minutes. Similarly the total plate count agar (Oxoid) used for determination of total viable organisms was sterilized by autoclaving at $121^{\circ} \mathrm{C}$ for 15 minutes, while the violet red bile agar (VRBA: Oxoid) used for determination of CC was sterilized by boiling (Richardson 1985). For both tests, the media used were prepared according to the guidelines given by the manufacturers. Each analysis was made in duplicate precession of the analysis was determined at 5 percent level.

Standard plate count (SPC): The total bacterial count was made by adding $1 \mathrm{ml}$ of milk sample into sterile test tube having $9 \mathrm{ml}$ peptone water. After thoroughly mixing, the sample was serially diluted up to $1: 10^{-7}$ and duplicate samples $(1 \mathrm{ml})$ were pour plated using $15-20 \mathrm{ml}$ standard plate count agar solution and mixed thoroughly. The plated sample was allowed to solidify and then incubated at $30^{\circ} \mathrm{C}$ for 48 hours. Colony counts were made using colony counter (Marth 1978).

Coliform count (CC): One $\mathrm{ml}$ of milk sample was added into sterile test tube having $9 \mathrm{ml}$ peptone water. After mixing, the sample was serially diluted up to $1: 10^{-5}$ and duplicate samples $(1 \mathrm{ml})$ were pour plated using $15-20 \mathrm{ml}$ Violet Red Bile Agar solution (VRBA). After thoroughly mixing, the plated sample was allowed to solidify and then incubated at $30^{\circ} \mathrm{C}$ for 24 hours. Finally, colony counts were made using colony counter (Marth 1978). Typical dark red colonies were considered as coliform colonies.

Titratable acidity test: Ten $\mathrm{ml}$ of milk was pipetted into a beaker and then 3-5 drops of 0.5 percent phenolphthalein indicator was added into the milk. Then the sample was titrated with $0.1 \mathrm{~N} \mathrm{NaOH}$ solution until definite pink colour persists (O'Connor 1994). Percent lactic acid was calculated as:

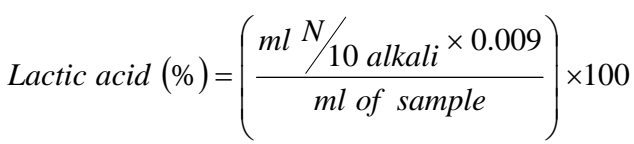

Alcohol test: Five $\mathrm{ml}$ of milk and $5 \mathrm{ml}$ of 68 percent alcohol (ethanol) were placed in a test tube. The test tube was inverted several times with the thumb held tightly over the open end of the tube. Then the tube was examined for formation of curd particles ( $\mathrm{O}^{\prime}$ Connor, 1994).

Clot-on-boiling test: Five $\mathrm{ml}$ of milk was placed in a test tube and it was placed in a boiling water bath for five minutes. Then, the test tube was carefully removed from the water bath and examined for the presence of floccules (O'Connor 1994).

Statistical Analysis: Analysis of variance for total bacteria count, coliform count and percent lactic acid was carried out using General Linear Model (GLM) procedure of SAS (2000). A fixed effect model was used to estimate the effects of locations and farm groups on the chemical composition and bacteriological tests. Predicted probabilities for cloton-boiling and alcohol were estimated in a logit response regression using SPSS version 12 (SPSS 2003). The number of microorganisms (colony forming units) per $\mathrm{ml}$ of milk was calculated using the following formula (IDF 1991).

$$
\text { Count }=S_{k} / n_{1}+0.1 n_{2} \times d
$$

Where, $S_{k}=$ sum of all colonies counted (between 10 and 300 )

$\mathrm{n}_{1}=$ number of plate from the lowest dilution used for computing the count,

$\mathrm{n}_{2}=$ number of plates in the next dilution factor used for computing the count,

$d=$ reciprocal of the dilution factor of the lowest dilution used for computing the count corresponding to $\mathrm{n}_{1}$

Total bacterial and coliform counts were log transformed before statistical analysis in order to make the frequency distribution more symmetrical. Mean comparisons were done using the Least Significant Difference (LSD) for variables whose Fvalues declared a significant difference. Differences were considered statistically significant at 5,1 , and/or $0.1 \%$ significance level.

The following model was used to analyses the microbiological quality of milk:

$Y_{i j}=\mu+\alpha_{i}+\beta_{j}+e_{i j}$

Where, $\mu$ is the overall mean, $Y_{i j}$ is the individual observation $\alpha$ is the $i^{\text {th }}$ locations effect 
$\beta$ is the $j^{\text {th }}$ farm groups effect and $\mathrm{e}_{\mathrm{ij}}$ is the error term

\section{RESULTS AND DISCUSSION}

Bacterial, coliform count and acidity: Table 1 shows the microbial counts and acidity of cows' milk produced in the study area. The overall mean total bacterial count of cows' milk produced in the study area was $7.58 \log _{10} \mathrm{cfu} / \mathrm{ml}$. The total bacterial count obtained in this study is generally high as compared to the acceptable level of $1 \times 10^{5}$ bacteria per $\mathrm{ml}$ of raw milk (O'Connor 1994). Fekadu (1994) reported that the minimum and maximum total bacterial count of raw cows' milk produced in southern region to be 6 to $8.8 \log _{10} c f u / m l$. Similarly, Alganesh (2002) reported total bacterial count of cows' milk produced in Bila Sayo and Guto Wayu districts of eastern Wollega to be $7.4 \times 10^{7}$ and $2.0 \times 10^{7} \mathrm{cfu} / \mathrm{ml}$, respectively. In general, lack of knowledge about clean milk production and use of unclean milking equipment would be some of the factors which contributed to the poor hygienic quality of milk produced in the study area.

The overall mean coliform count of milk produced in the area was $4.49 \log _{10} \mathrm{cfu} / \mathrm{ml}$ (Table 1). The coliform count obtained in the current study is greater than that reported by Fekadu (1994) who found coliform counts of 3.8, 4.0 and $3.8 \log _{10} \mathrm{cfu} / \mathrm{ml}$ for cows' milk produced in Aneno, Gulgula and Dongora districts of southern region, respectively. On the other hand, Zelalem and Bernard (2006) obtained higher coliform count of $6.57 \log _{10} \mathrm{cfu} / \mathrm{ml}$ for cows' milk collected from different producers in the central highland of Ethiopia. The higher coliform count observed in this study may be due to the initial contamination of the milk samples either from the cows, the milkers, milk containers and the milking environment. Thus, extension services and training of farmers in improved milk handling practices are required to improve the raw milk quality in the study area.

The overall mean titratable acidity of cows' milk produced in the study area was 0.23 percent (Table 1). This figure is lower than the finding of Alganesh (2000) who reported an average acidity of 0.28 and 0.31 percent for raw cows' milk produced in Bila Sayo andd Guto Wayu districts of eastern Wollega, respectively. On the other hand, Taye (1998) reported a much higher value $(0.38 \%)$ of titratable acidity for milk produced from crossbred cows around Asela. In general, the high percent lactic acid of milk observed in the present study implies that the manner in which the milk was handled was poor reflecting the substandard hygienic conditions during production and handling of milk in the area.

Table 1. Least squares means $( \pm \mathrm{SE})$ of microbial counts $(\log 10 \mathrm{cfu} / \mathrm{ml})$ and acidity of milk produced in the study area

\begin{tabular}{|l|l|l|l|}
\hline Variables & $\begin{array}{l}\text { Total bacterial count }\left(\log _{10}\right. \\
\text { cfu/ml) }\end{array}$ & $\begin{array}{l}\text { Coliform count } \\
\left(\log _{10} \text { cfu/ml) }\right.\end{array}$ & $\begin{array}{l}\text { Acidity } \\
\text { (\%lactic acid) }\end{array}$ \\
\hline Overall mean $(\mathrm{N}=84)$ & $7.58 \pm 0.09$ & $4.49 \pm 0.11$ & $0.23 \pm 0.01$ \\
\hline Location & $\mathrm{ns}$ & $\mathrm{ns}$ & $\mathrm{Ns}$ \\
\hline Bahir Dar Zuria $(\mathrm{N}=39)$ & $7.61 \pm 0.12$ & $4.41 \pm 0.16$ & $0.22 \pm 0.01$ \\
\hline Mecha (N=45) & $7.56 \pm 0.13$ & $4.55 \pm 0.15$ & $0.23 \pm 0.01$ \\
\hline Farm groups & $\mathrm{ns}$ & $\mathrm{ns}$ & $\mathrm{Ns}$ \\
\hline Local cows' milk $(\mathrm{N}=45)$ & $7.70 \pm 0.13$ & $4.52 \pm 0.15$ & $0.23 \pm 0.01$ \\
\hline Crossbred cows' milk (N=39) & $7.47 \pm 0.11$ & $4.45 \pm 0.15$ & $0.22 \pm 0.01$ \\
\hline
\end{tabular}

$\mathrm{N}=$ number of observations; $\mathrm{ns}=$ not significant $(\mathrm{P}>0.05)$; cfu = colony-forming units

Table 2. Least squares means $( \pm$ SE) of microbial counts $(\log 10 \mathrm{cfu} / \mathrm{ml})$ and acidity of milk obtained from individual farmers and dairy cooperatives in Bahir Dar Zuria district

\begin{tabular}{|l|l|l|l|}
\hline Variables & $\begin{array}{l}\text { Total bacterial count } \\
\left(\log _{10} \text { cfu/ml) }\right.\end{array}$ & $\begin{array}{l}\text { Coliform count } \\
\left(\log _{10} \text { cfu/ml) }\right.\end{array}$ & $\begin{array}{l}\text { Acidity } \\
\text { (\%lactic acid) }\end{array}$ \\
\hline Farm groups & $\mathrm{NS}$ & $\mathrm{NS}$ & ${ }^{*}$ \\
\hline Individual farmers $(\mathrm{N}=39)$ & $7.61 \pm 0.12$ & $4.41 \pm 0.16$ & $0.23^{\mathrm{b}} \pm 0.01$ \\
\hline Cooperatives $(\mathrm{N}=6)$ & $8.12 \pm 0.25$ & $4.94 \pm 0.23$ & $0.28^{\mathrm{a}} \pm 0.01$ \\
\hline
\end{tabular}

Means with different superscript letters in column are significantly different, ${ }^{*} \mathrm{P}<0.05$; $\mathrm{ns}=$ not significant; $\mathrm{N}=$ number of observations; cfu = colony-forming units. 
The least squares means and standard error of the milk samples collected from individual farmers and dairy cooperatives in Bahir Dar Zuria district are presented in Table 2. Total bacterial count of milk obtained from individual farmers did not differ significantly from milk collected from the dairy cooperatives. The highest TBC was recorded for milk samples obtained from cooperatives. The highest TBC observed in milk samples collected from the cooperatives might have been due to the time spent by the different farmers while delivering milk to the cooperatives and the poor receiving environment at the dairy cooperatives. Bekele and Bayileyegn (2000) reported a mean total bacterial count of $1.3 \times 10^{7}$ cfu/ml for raw cows' milk obtained at milk collection centers in and around Addis Ababa city.

Although no significant difference in CC was observed between milk samples obtained from individual farmers and the dairy cooperatives; milk samples collected from the dairy cooperatives had higher $\mathrm{CC}$ than milk samples collected from individual farmers.

Milk samples collected from the dairy cooperatives had higher acidity $(P<0.05)$ than milk samples obtained from individual farmers (Table 2). The increased acidity in the milk collected from the dairy cooperatives might be attributed to proliferation of microorganisms during delivery of milk by farmers and further contamination at the dairy cooperatives. The titratable acidity of milk obtained from dairy cooperatives in Bahir Dar Zuria district is lower than the value reported by Taye (1998), which was 0.50 percent for milk samples collected from cooperative farms around Asela. However, the titratable acidity of milk collected from the dairy cooperatives in the current study is in agreement with 0.27 percent reported by Zelalem and Bernard (2006) for milk samples collected at dairy product shops in the central highlands of Ethiopia.
In general, the microbiological quality of milk obtained from the dairy cooperatives is poor as compared to milk samples obtained from individual farmers. Thus, this calls the need for stringent measures to improve the hygienic quality of milk at the dairy cooperatives.

Clot-on-boiling test: The predicted probability and standard error of clot-on-boiling test for cow milk samples collected in the study area are presented in Table 3. This test showed that 23 percent of the milk samples tested is likely to clot- on- boiling. Alganesh (2002) reported an overall mean value of 21 percent for cow milk samples collected from smallholder farmers in eastern Wollega of Oromia region. This test measures the same characteristics as the alcohol test but is somewhat more lenient than alcohol test (O'Connor, 1994).

Alcohol test: Table 3 shows the predicted probability and standard error of alcohol test for cow milk samples collected in the study areas. The overall mean value shows that 51 percent of the milk samples tested are likely to clot by the alcohol test. The report of Alganesh (2002) indicated that 58 percent of cow milk samples collected from smallholder farmers in eastern Wollega of Oromia region is likely to clot by alcohol test. These observations support the view that the alcohol test is more sensitive than the clot-on-boiling test as reported by O'Connor (1994).

The predicted probabilities and standard error of cloton-boiling and alcohol test of milk samples collected from individual farmers and dairy cooperatives in Bahir Dar Zuria district are presented in Table 4. The present study showed that more of the milk samples collected from the dairy cooperatives is likely to clot by both tests as compared to the milk samples collected from individual farmers (Table 4). This result is in agreement with the higher percent of lactic acid observed in the milk samples collected from the dairy cooperatives (Table 2).

Table 3. Predicted probabilities $( \pm \mathrm{SE}$ ) for clot-on-boiling and alcohol tests of cow's milk produced in the study area

\begin{tabular}{|l|l|l|}
\hline Variables & Clot-on-boiling test & Alcohol test \\
\hline Overall mean $(\mathrm{N}=84)$ & $0.23 \pm 0.12$ & $0.51 \pm 0.11$ \\
\hline Location & & $0.50 \pm 0.10$ \\
\hline Bahir Dar Zuria (N=39) & $0.26 \pm 0.12$ & $0.54 \pm 0.11$ \\
\hline Mecha (N = 45) & $0.23 \pm 0.13$ & \\
\hline Farm groups & & $0.55 \pm 0.12$ \\
\hline$\quad$ Local cow's milk (N=45) & $0.27 \pm 0.13$ & $0.49 \pm 0.10$ \\
\hline$\quad$ Crossbred cow's milk (N=39) & \\
\hline $\mathrm{N}=$ number of observations. & $0.23 \pm 0.09$ & \\
\hline
\end{tabular}


Table 4. Predicted probabilities $( \pm S E)$ for clot- on- boiling and alcohol tests of milk obtained from individual farmers and dairy cooperatives in Bahir Dar Zuria district

\begin{tabular}{|l|l|l|}
\hline Variables & Clot-on-boiling test & Alcohol test \\
\hline Farm groups & & \\
\hline Individual farmers $(\mathrm{N}=39)$ & $0.26 \pm 0.12$ & $0.50 \pm 0.10$ \\
\hline Cooperatives $(\mathrm{N}=6)$ & $0.57 \pm 0.15$ & $0.78 \pm 0.2$ \\
\hline $\mathrm{N}=$ number of observations & & \\
\hline
\end{tabular}

\section{CONCLUSIONS AND RECOMMENDATIONS:}

The present study showed that the quality of milk produced in the study area was poor. This was evident from the high values of total bacterial count (TBC), coliform count (CC) and high lactic acid percentage in the milk. Hence, adequate sanitary measures should be taken at stage of from production to consumption. These measures include proper handling of the cow, personnel hygiene, use of hygienic milking and processing equipments, improving milk and milk handling environment among others. The poor bacteriological quality observed in the present study requires further investigation of the status of the animals' health, especially mastitis and the significance of the effect of containers to ascertain their contribution on microbial quality.

\section{ACKNOWLEDGEMENTS:}

This study was funded by the Amhara Regional Agricultural Research Institute.

\section{REFERENCES}

Alganesh Tola 2002 Traditional milk and milk products handling practices and raw milk quality in Eastern Wollega. M.Sc. Thesis, Alemaya University. Dire Dawa, Ethiopia. 108p.

Bekele Godefay and Bayileyegn Molla 2000 Bacteriological qaulity of raw cow's milk from four dairy farms and a milk collection center in and around Addis Ababa. Berl. Munch Tierarzti. Wschr. 113:276-278.

Eyassu Seifu 1998 Chemical composition, microbiological properties and keeping quality of raw and pasteurized goat's milk. M.Sc. Thesis, Alemaya University. Dire Dawa, Ethiopia. 98p.

Fekadu Beyene 1994 Present situation and future aspects of milk production, milk handling and processing of dairy products in Southern Ethiopia. Food production strategies and limitations: The case of Aneno, Bulbula and Dongora in Southern Ethiopia. Ph.D. Thesis, Department of Food Science. Agricultural University of Norway. Norway.

International Dairy Federation (IDF) 1990 Milk collection in warm developing countries. Squre Vergote, Brussels, Belgium. pp. 57-59.

Marth E H (ed.) 1978 Standard Methods for the Examinations of Dairy Products. American Public Health Association, Washington, DC. 416p.

Mogessie Ashanafi 1990 Microbiological quality of Ayib, a traditional Ethiopian cottage cheese. International Journal of Food Microbiology. 10 (1990): 263-268.

O'Connor C B 1994 Rural Dairy Technology. ILRI training manual No. 1. International Livestock Research Institute (ILRI), Addis Ababa, Ethiopia. 133p.

O'Mahony F 1988 Rural dairy technology experiences in Ethiopia. ILCA Manual No. 4. Dairy Technology Unit. ILCA, Addis Ababa, Ethiopia. 64p.

Richardson G H 1985 Standard Methods for the Examination of Dairy Products. $15^{\text {th }}$ ed. American Public Health Association. Washington, D. C. pp. 168196.

SAS 2000 SAS Users' guide, Statistical Analysis System (SAS) Institute,Inc, Cary, NC.

SPSS 2003 (Statistical Package for Social Sciences). SPSS version 12 application guide. SPSS Inc.

Taye Tolemariam 1998 Qualities of cow milk and the effect of lactoperoxidase system on preservation of milk at Arsi, Ethiopia. M. Sc. Thesis, Alemaya University of Agriculture, Dire Dawa, Ethiopia. 62p.

Zelalem Yilma and Bernard Faye 2006 Handling and microbial load of cow's milk and irgo- fermented milk collected from different shops and producers in central highlands of Ethiopia. Ethiopian Journal of Animal Production. 6(2)-2006:67-82. 